\title{
モジュラリティに基づくリサーチフロントと学問の階層構造の分析
}

\section{Analysis of Research Front and Hierarchical Structure of Science}

\section{Based on Modularity}

\author{
武田善行 ${ }^{*}$, 梶川裕矢 \\ Yoshiyuki TAKEDA, Yuya KAJIKAWA
}

東京大学大学院工学系研究科

Graduate School of Engineering, The University of Tokyo

于113-8656 東京都文京区弥生2-11-16工学部9号館

E-mail: takeda@biz-model.t.u-tokyo.ac.jp

共引用や書誌結合を用いたクラスタリング手法は学問領域の構造を分析する有力な手段であるが, クラスタリング時の閾值設定の恣意性が問題となる. 本研究では, 複数の学問領域に対し, 引用ネッ トワークのモジュラリティを追跡した。結果，引用ネットワークのクラスタリングは3つの段階からなり， その構造は対象分野によらないことが分かった. 第一段階では, 分野のコアとなるクラスタが形成し, 成長する. 第二段階ではコアクラスタの成長と並行して, 周辺的なクラスタが形成される. 第三段階 では，再びコアクラスタが成長する. このようにクラスタリングの素過程に着目することで，最終的なク ラスタリング結果からは見ることのできない，学問の階層構造や各論文の位置づけを判断することが できる.

Clustering using cocitation and bibliographic coupling is an effective tool to analyze the structure of scientific research, but its arbitrariness in the setting of clustering threshold is a problem. This study tracked modularity of citation networks in research domains, and we found that there are three stages in clustering of citation networks and it is universal across our case studies. In the first stage, core clusters in the domain are formed. In the second stage, peripheral clusters are formed, while core clusters continue to grow. In the third stage, core clusters grow again. By focusing on elementary process in clustering, we can understand a hierarchical structure of domain and judge the location of each paper, which cannot be seen in the final clustering results.

キーワード：引用分析，リサーチフロント，階層構造，モジュラリティ

citation analysis, research front, hierarchy, modularity

\section{1 緒言}

学術論文の引用情報に基づいた文書ク
ラスタリングは，膨大な数の学術論文か ら成る研究分野を俯瞰するための重要な 方法である ${ }^{[1,2]}$. 計量書誌学の分野では, 
文章間の類似度を測る手法として，共引 用 ${ }^{[3]}$, ならびに書誌結合 ${ }^{[4]}$ が用いられて きた。例えば, Smallは共引用を用いて医 学や材料科学分野の学術文献群をクラス タリングすることで, 萌芽期にある重要 な学術分野を特定することに成功してい る ${ }^{[5]}$. またTakedaらは直接引用を類似度 も指標として，学術分野の俯瞰や近年の 論文数の増加の大きいアクティブな研究 分野の特定を行っている ${ }^{[6,7]}$.

しかし，文書クラスタリング手法には， 文書間の類似度の設定方法，その後のク ラスタリングの際の停止条件の選択にお ける染意性が問題となる，そのようなク ラスタリング条件の選択が結果に及ぼす 影響を調べた論文は必ずしも多くない。

例えば, Klavans-Boyackは, 学術雑誌の 引用ネットワークを対照として, 類似度 の設定方法として, 共引用と直接引用を 用いたいくつかの類似度指標の有効性の 比較検討を行っている ${ }^{[8]}$. その結果, 直 接引用は，共引用よりも優れたパフォー マンスを示すことが分かっている.

本研究の目的は, 直接引用を用いて文 書クラスタリングを行う際の停止条件の 検討を行うことである.クラスタリング のステップ数を変化させた時のネットワ 一クの構造を分析することで，クラスタ リングが進むにつれ, 結果がどのように 変化するかを追跡する. 複数のコーパス に対し，同様の分析を行うことで，学術 論文の引用ネットワークに共通の構造を 抽出する.

\section{2 手法}

本研究が対象とした学術分野は，1) エネルギー資源(E\&F)，2)燃料電池(FC),
3)太陽電池(SC), 4)化学気相成長法(CVD), 5)ナノバイオテクノロジー(NB)である. 書誌情報の収集には, Institute for Scientific Information (ISI) Web of Scienceを用いた。 1)はISI- Journal Citation Reports中, Energy and Fuelsに分類される 68ジャーナルに掲載された全論文，2)-4) は，それぞれ，”fuel cell*”, “solar cell*”, “chemical vapor deposition”, “nano* and bio*”を検索語として収集した。収集した データに含まれている引用情報に基づき， 最大連結成分を取得し, 分析対象とした. ただしその際，収集した論文の引用先も ノードとして追加している. 結果, 最大 連結成分にはそれぞれ，1,088,444 (E\&F), 152,164 (FC), 154,445 (SC), 471,509 (CVD), 451,329 (NB)のノードが含まれる.

上記，最大連結成分に対し, Newman 法 [9]を用いてクラスタリングを行った。 Newman 法はモジュラリティ(Q)に基づ きクラスタリングを行う。 Q は次式で定 義される。

$$
Q=\sum_{s=1}^{N_{m}}\left[\frac{l_{s}}{l}-\left(\frac{d_{s}}{2 l}\right)^{2}\right]
$$

ここで, $\mathrm{N}_{\mathrm{m}}$ はクラスタ数, $\mathrm{l}$ はネットワ 一ク内におけるリンクの数, $\mathrm{l}_{\mathrm{s}}$ はクラス タ $\mathrm{s}$ 内におけるリンク数, $\mathrm{d}_{\mathrm{s}}$ は, クラスタ $\mathrm{s}$ 内に存在するノードのリンク数の合計 である. Qが示すものは，[モジュール内 でのノード間にリンクが存在する確率の 実測值]一[ランダムネットワークと仮定 した場合のモジュール内におけるリンク の割合の理論值]である. Newman 法にお けるクラスタリングの停止点は通常, Q が最大となるところに設定される。つま り，クラスタ内のリンク数がクラスタ間 
のリンク数に比べ, 最も大きくなる地点 で凝集的なクラスタリングを停止する. $\mathrm{Q}$ の最小值は 0 であり, クラスタリング された構造がランダムであることを示す。 $\mathrm{Q}$ が大きいほどクラスタの独立性が高く なる. 最終的に全てのクラスタが凝集し, ネットワーク内のクラスタ数が 1 と成る 時 $\mathrm{Q}=1$ である.

\section{3 結果と考察}

図1はクラスタリング時におけるステ ップ数に対するQ值の変化を示したもの である.Q值はステップ数4万程度までは 複数の変曲点が見られるが, その後は緩 やかな凸の関数となり, step数約 15 万で 最大值に達した後, 急速に減少する. 図 はFCにおけるものを例と示しているが, 我々が行った 5 つの分野, 全てにおいて 同様の傾向が見られた。

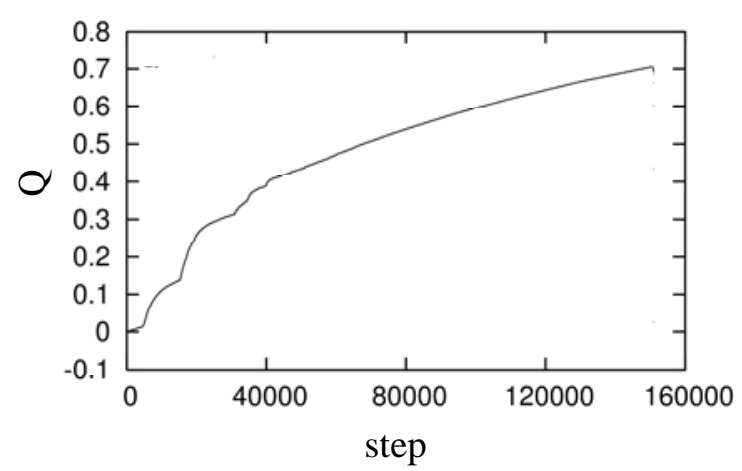

図1 クラスタリングの進展に伴うQ值の変化

クラスタ内リンク密度を最大, クラス タ間リンク数密度を最小にするというク ラスタリングの観点からは，Qが最大と なる点 $\left(\mathrm{Q}_{\max }\right)$ をクラスタリングの停止条 件とするのが適切であるが，その間にど のようにクラスタリングが進展している のかは明らかでない。

その点を確かめるため, クラスタリン グの各stepにおいて凝集する 2 つのク スタのうち，ノード数の大きい方のクラ スタのノード数(クラスタのサイズ)を図 2(a)に，小さい方のクラスタのサイズを 図2(b)に示寸. 図 2 から, step数約 4 万程 度以前のクラスタリングの初期段階には, 特定のクラスタがノード数10未満の小さ いクラスタを吸収しながら成長している ことが読み取れる。しかし，クラスタリ ングの中盤(ステップ数約 4 万〜 10 万)に おいては, 主に数十〜数百程度のサイズ のクラスタが合一を繰り返しており, ク ラスタリングの終盤(ステップ数 約15 万)では, 初期に形成したクラスタが再 び成長している。この過程もまた, 我々 が分析対象とした $5 つ の$ 分野全てにおい て共通であった。

(a)
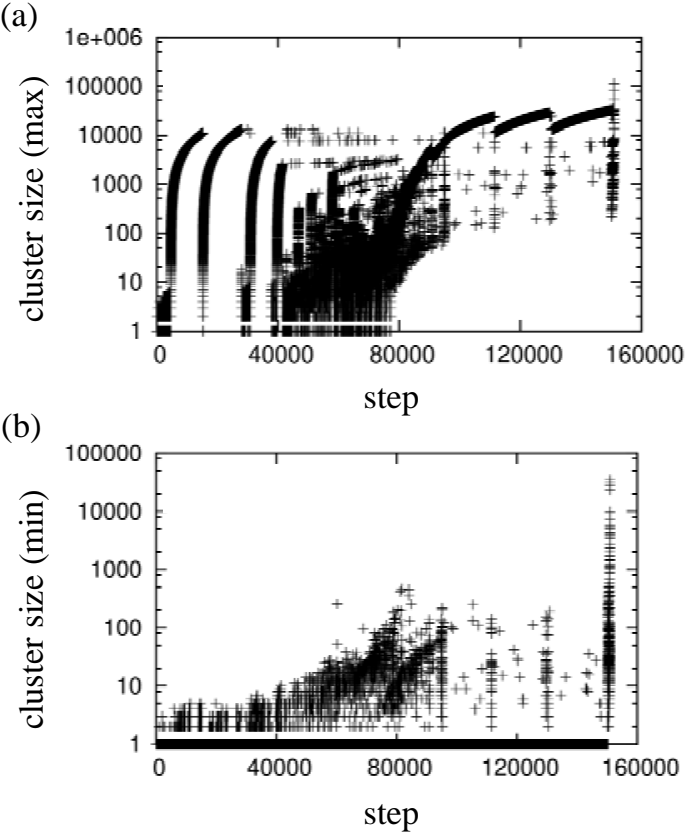

図2 各ステップにおけるクラスタサイズ

以上に示した引用ネットワークのクラ スタリングの様子を模式的に表したもの が図 3 である.クラスタリングの過程は 3 つの段階に分かれる. 初期課程(I)にお 
いては, 各分野においてコアとなる少数 のクラスタが個別の論文もしくは, サイ ズの小さな(概衫10以下)クラスタを吸収 しながら優先的に成長する.この段階で 形成されるクラスタを以降クラスタ Aと 呼ぶ. クラスタAはクラスタリングの後 期課程(III)においてもサイズが他に比し て大きく, それぞれの分野における主要 クラスタであると見做せる.

次に，より小さなサイズのクラスタが 形成される中期過程(II)がある。この段 階で形成されるクラスタをクラスタ $\mathrm{B}$ 呼ぶ。この中期に形成されるクラスタ $\mathrm{B}$ はクラスタ Aと同様, その形成初期には 個別論文や概衫10以下の論文から成る小 さなサイズのクラスタを集めながら成長 寸る. しかし, その後は互いに融合を繰 り返しながら, クラスタリングが進展す る.ただしこの第II期に形成されるクラ スタBはクラスタ Aに比べクラスタ数は 多いものの, それぞれのクラスタのサイ ズは小さく各分野の中堅クラスタである と見做せる.

クラスタリングの後期(III)においては クラスタ Aが再び個別論文，もしくは小 さなクラスタを吸収しながら成長を始め る.この段階でクラスタAに取り込まれ るノードは初期(I)に取り込まれるノード に比べ，コーパス全体の中で周辺的な位 置を占めていると推察できる.

またクラスタリングを $\mathrm{Q}=\mathrm{Q}_{\max }$ となる ステップ数を超えて進展させた場合(ク ラスタリングの最終段階IV), クラスタ A 同士においても, クラスタの併合が起き る. 結果, Q值は大きく低下し, 得られる クラスタ構造はランダムなものに近づい ていく、すなわち, 適切なクラスタリン
グ結果とはいえなくなってくる.

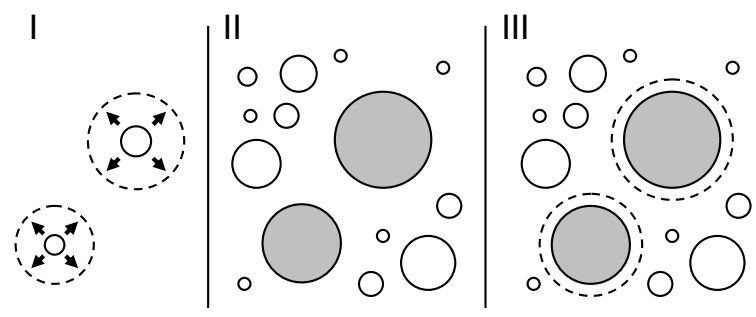

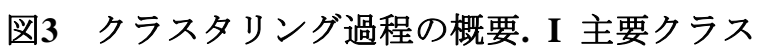
タ形成期, II 中堅クラスタ形成期, III 主要クラ スタ成長期.

以上の分析結果から, 引用ネットワー クのクラスタリング結果を解釈する場合 に対し, 以下の示唆が得られる。まず, 各研究分野における中心的な研究分野 (クラスタ A) と, 周辺的な研究分野(クラ スタB)の峻別である.クラスタ A そその サイズ, 密度ともにクラスタBを大きく 上回ることからその分野の主要な研究卜 ピックを包含していると思われる.一方， クラスタBはそのクラスタ群内の密度 $(1$ ノード当たりのリンク数)が, クラスタ $\mathrm{A}$ 群内のそれに比して小さく(表1), クラス タAに関して未成熟であると思われる。 またそれらは，クラスタリングの中期 (II)において複数のクラスタが合一した 結果として形成されたものであり，その 内部には異なる複数の結果が含まれると 考えられる.また, 内部の密度が低いこ とからクラスタリング時の頑健性も低い ことが予想され, 結果の解釈には注意が 必要である.ただし, クラスタAにおい ても, クラスタリング後期(III)で取り込 まれたものに関しては, クラスタ内の他 の論文との関連性が低いと思われること から，その部分に関しては注意が必要で ある。 


\begin{tabular}{c|ccccc} 
表 1 & \multicolumn{3}{c}{ ネットワークの密度 } \\
& E\&F & FC & SC & CVD & NB \\
\hline A群 & 1.95 & 2.77 & 2.47 & 2.76 & 2.12 \\
B群 & 1.11 & 1.10 & 1.14 & 1.15 & 1.14
\end{tabular}

\section{4 結言}

結果，引用ネットワークのクラスタリ

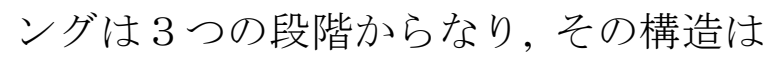
対象分野によらないことが分かった. 第 一段階では, 分野のコアとなるクラスタ が形成し，成長する。第二段階ではコア クラスタの成長と並行して, 周辺的なク ラスタが形成される. 第三段階では, 再 びコアクラスタが成長する. 以上の結果 は, クラスタリング結果の解釈に対し, 各領域・論文の中心性, 結果の頑健性と いう点において有用な指針を与える。

\section{参考文献}

[1] Small, H.: "Visualizing science by citation mapping”, Journal of the American Society for Information Science, Vol.50, pp.799-813, 1999.

[2] Börner, K.; Chen, C.; Boyack, K.W.: "Visualizing knowledge domains", Annual Review of Information Science \& Technology, Vol.37, pp.179-255, 2003.
[3] Small, H.: "Co-citation in the scientific literature: A new measure of the relationship between two documents", Journal of the American Society for Information Science, VOl.24, pp.265-269. 1973.

[4] Kessler, M.M.: "Bibliographic coupling between scientific papers”, American Documentation, Vol.14, pp.10-25, 1963.

[5] Small, H.: "Tracking and predicting growth areas in science”, Scientometrics, Vol.68, pp.595-610, 2006.

[6] Takeda, Y. Kajikawa, Y., Matsushima, K.: "Citation network of CVD research: research topics and journals”, Chemical Vapor Deposition, Vol.10, pp.523-525, 2007. [7] Takeda, Y.; Mae, S.; Kajikawa, Y.; Matsushima K.: "Nanobiotechnology as an emerging research domain from nanotechnology: A bibliometric approach", Scientometrics, in press.

[8] Klavans, R.; Boyack, K.W.: "Identifying a Better Measure of Relatedness for Mapping Science”, Journal of the American Society for Information Science and Technology, VOl.57, pp.251-263, 2006.

[9] Newman, M.E.J.: "Fast algorithm for detecting community structure in networks", Physical Review E, VOl.69, artNo.066133, 2004. 